Article

\title{
Resolving the Gettier Problem in the Smith Case: The Donnellan Linguistic Approach
}

\section{Joseph Martin M. Jose Napoleon M. Mabaquiao, Jr.}

\begin{abstract}
In this paper, we contend that the "Smith case" in Gettier's attempt to refute the justified true belief (JTB) account of knowledge does not work. This is because the said case fails to satisfy the truth condition, and thus is not a case of JTB at all. We demonstrate this claim using the framework of Donnellan's distinction between the referential and attributive uses of definite descriptions. Accordingly, the truth value of Smith's proposition "The man who will get the job has ten coins in his pocket" partly depends on how Smith uses the definite description "the man who will get the job" when he utters the proposition. Since, upon uttering the proposition, Smith has in mind a particular individual, namely Jones, and not just whoever will fit the attribute specified in the definite description, Smith uses the definite description referentially. And so when it turns out that it is Smith who eventually gets the job, the definite description fails to refer to Jones as intended by Smith, thereby making Smith's proposition false. To think that Smith's proposition is still true, in this regard, is to use the definite description attributively - that it is about whoever will fit the definite description. Apparently, when Gettier claims that Smith's proposition is still true, to demonstrate that it is a case of JTB, he, in effect, imposes his attributive understanding of Smith's usage of the definite description on Smith's own epistemic situation.
\end{abstract}

Keywords: Gettier, Donnellan, Gettier problem, definite descriptions

\section{Introduction}

ccording to the traditional understanding of knowledge (henceforth
understood as propositional knowledge ${ }^{1}$ ), knowledge is constituted by
three individually necessary and jointly sufficient conditions;

${ }^{1}$ Propositional knowledge is the kind of knowledge whose content is expressible in the form of a proposition and thus is truth-bearing. It is usually distinguished from practical knowledge, referring to knowledge of skills and procedures, and knowledge by acquaintance, referring to knowledge understood as familiarity with persons, places, and others. The contents of these two other kinds of knowledge are non-truth-bearing; that is, they cannot be said to be either true or false. The Gettier problem only concerns propositional knowledge.

(c) 2018 Joseph Martin M. Jose and Napoleon M. Mabaquiao, Jr. https://www.kritike.org/journal/issue 23/jose\&mabaquiao december2018.pdf ISSN 1908-7330 
namely: justification, truth, and belief. This understanding has been referred to as the Tripartite Analysis of Knowledge or the Justified True Belief (JTB) Account of Knowledge. Formally put, it claims that $S$ (standing for the subject) knows that $p$ (standing for any proposition) if and only if: (1) $S$ believes that $p ;(2) p$ is true; and (3) $S$ is justified in believing that $p$ is true. Throughout the history of philosophy, this account, it is safe to say, has been the long-held and accepted view by most analytic epistemologists. This, however, has been challenged by Edmund Gettier in his seminal paper "Is Justified True Belief Knowledge?" by presenting two cases (now called Gettier cases) which served as counterexamples to the JTB definition of knowledge. ${ }^{2}$ Gettier's critique can be summarized in the following argument:

P1: If JTB is a correct account of knowledge, then in all instances where JTB obtains, knowledge likewise obtains.

P2: There are instances where JTB obtains but knowledge does not obtain.

C: Therefore, JTB is not a correct account of knowledge.

Gettier's two cases are intended to instantiate P2. Different scholars, to defend the JTB account of knowledge, have used a variety of strategies to respond to the challenge of the Gettier cases. Jonathan Dancy distinguishes three general types of these strategies: "(1) find some means to show that the counterexamples do not work; (2) accept the counter-examples and search for a supplement to the tripartite analysis which excludes them; (3) accept the counter-examples and alter the tripartite analysis to suit rather than adding anything to it." 3 Most of the classical attempts to resolve the Gettier problem have focused on the strategy that seeks to modify certain aspects of the JTB account, either by adding supplementary conditions to the JTB conditions or by qualifying some or all of them to accommodate the Gettier cases. ${ }^{4}$ In our

\footnotetext{
${ }^{2}$ Edmund Gettier, “Is Justified True Belief Knowledge?,” Analysis, 23:6 (1963), 121-123.

${ }^{3}$ Jonathan Dancy, An Introduction to Contemporary Epistemology (Oxford: Blackwell Publishing, 1985), 26.

${ }^{4}$ Examples of attempts that have made use of this strategy include the following: the Infallibility Proposal which argues that we must make sure that in our cases of JTB one's justification for one's belief that p should be infallible [see Keith Lehrer, "Why Not Skepticism?," The Philosophical Forum, 2 (1971), 283-298, and Peter Unger, "A Defense of Skepticism," The Philosophical Review, 80:2 (1971), 198-219]; the Eliminating Luck Proposal which argues that we must remove any presence of luck in one's cases of JTB [see Peter Unger, "An Analysis of Factual Knowledge," Journal of Philosophy, 65:6 (1968), 157-170]; the No False Evidence Proposal which suggests that none of our evidence, by which we have a justified true belief, is false [see Richard Feldman, "An Alleged Defect in Gettier Counterexamples," Australasian Journal of Philosophy, 52 (1974), 68-69.]; the No Defeat Proposal which suggests that there be no defeaters in our evidences for having a justified true belief [see Keith Lehrer and Thomas Paxson, "Knowledge: Undefeated
} 


\section{RESOLVING THE GETTIER PROBLEM}

case, we shall endeavor to respond to the Gettier problem using the strategy that shows that the Gettier cases are problematic in themselves and that they do not work at all. We shall, however, focus only on the first Gettier case, known as the Smith case. We intend to demonstrate that this case is not a case of JTB at all and that there is a confusion in Gettier's understanding of Smith's epistemic situation. Crucial to our analysis is how Smith uses the definite description "the man who will get the job" upon uttering the proposition "The man who will get the job has ten coins in his pocket." The framework that we shall use for our analysis shall be Keith Donnellan's distinction between the referential and attributive uses of definite descriptions. Given this distinction, we shall argue that Gettier misunderstands Smith's epistemic situation with regard to the usage of the definite description in Smith's proposition. Basically, we contend that Smith is using the definite description referentially since he has a particular person in mind, namely, Jones, when he utters the proposition containing the definite description, and not whoever will fit the attribute indicated by the definite description. This means that Smith's proposition is false when in turns out that it is he, not Jones, who will get the job; and, consequently, fails to instantiate P2. To say that the proposition is still true, as Gettier does, is to wrongly impute an attributive usage to the definite description in Smith's proposition.

We shall divide our discussion into three parts. In the first part, we shall briefly expound on the JTB account of knowledge and present the Gettier problem as expressed in the first case. This will give us a better handle of the issue being addressed in the paper. In the second part, we shall provide a brief survey of the various approaches to the Gettier problem. This will distinguish our framework in handling the Gettier problem from the others. In the third part, we will explicate Donnellan's theory of definite descriptions and then apply this theory in resolving the Gettier problem in the Smith case.

Justified True Belief," Journal of Philosophy, 66:8 (1969), 225-237]; and the Appropriate Causality Proposal which suggests that $S^{\prime}$ s belief that $\mathrm{p}$ should be causally connected with $S^{\prime}$ s believing that p [see Alvin Goldman, "A Causal Theory of Knowing," Journal of Philosophy, 64:12 (1967), 357372]. Other attempts using other strategies include the following: the Competing Intuitions Approach, which point that there is a discrepancy between the intuitions of lay people and the intuitions of professional epistemologists; thus, posing problems on the interpretation of the Gettier cases itself [see Jonathan Weinberg, Shaun Nichols, and Stephen Stich, "Normativity and Epistemic Intuitions," Philosophical Topics, 29:1/2 (2001), 429-460]; and the Knowing Luckily Proposal which argues that although we cannot eliminate the presence of luck (strange occurrence/s) in some of our experiences of knowing, it does not diminish its status of being knowledge [see Stephen Hetherington, Good Knowledge, Bad Knowledge: On Two Dogmas of Epistemology (Oxford: Oxford University Press, 2000), 70-107].

(c) 2018 Joseph Martin M. Jose and Napoleon M. Mabaquiao, Jr. https://www.kritike.org/journal/issue 23/jose\&mabaquiao december2018.pdf ISSN 1908-7330

(cc) BY-NC-ND 


\section{JTB and Gettier's Smith Case}

As already noted, according to the JTB account of knowledge, knowledge consists of the three individually necessary and jointly sufficient conditions; namely: belief, truth, and justification. These three conditions are individually necessary for knowledge in that the absence of any of them would mean the absence of knowledge. They are, however, jointly sufficient in that the three of them together is enough to explain the occurrence of knowledge. To fully understand Gettier's critique of this account, let us briefly delve into each of the JTB conditions.

First, in order to say that we know that $p$, it is necessary that we believe that $p$. If we claim to know that Manila is the capital of the Philippines, for instance, it is necessary that we believe that Manila is the capital of the Philippines. What makes belief a necessary condition for knowledge can be explained via the Speech Act Theory developed by J.L. Austin and John Searle. ${ }^{5}$ For this theory, belief is the sincerity condition for assertives, the class of speech acts under which propositions are classified (along with descriptions, classifications, and explanations, among others). As Searle explains: "An assertive is always an expression of a belief." ${ }^{6}$ This means that we can only be said to be stating a proposition if at the time that we utter it our mental state or attitude towards the content of this proposition is one of belief. If we do not believe in the content of our proposition, our purpose for uttering the proposition is presumably other than to express a knowledge claim, say perhaps to mislead some people. For instance, if I believe that it is not raining and I tell a person that it is, my purpose in doing so is presumably not to tell

${ }^{5}$ Beliefs belong to what are called "intentional states" in the philosophy of mind, referring to a class of mental states whose mentality derives from their inherent directedness towards possible objects or states of affairs in the world. They are usually distinguished from the so-called "phenomenal states," whose mentality derives from their phenomenal feel or "what-itis-like" properties (paradigm examples are pains). When intentional states particularly concern possible states of affairs, they are usually called "propositional attitudes," a term coined by Bertrand Russell in consideration of their two main components: content and quality. Their content, which is expressible in the form of a proposition, refers to the possible state of affairs they are directed to; while their quality refers to their kind of attitude towards their content. Thus, "I believe that $\mathrm{p}$ " and "I hope that $\mathrm{p}$ " are propositional attitudes having two different attitudes towards the same content; whereas "I believe that $\mathrm{p}$ " and "I believe that $\mathrm{q}$ " are propositional attitudes having the same attitude towards different contents. Since the contents of propositional attitudes are either correct or incorrect representations of states of affairs in the world, they are thus truth-bearing, that is, they are either true or false. Now, the attitude of beliefs, in contrast to other propositional attitudes such as hopes, desires, and fears, is to assert the truth of their contents. See Napoleon Mabaquiao, Jr., Mind, Science and Computation (Quezon City: Vibal Publishing, Inc. and De La Salle University, 2012), 55-57.

${ }^{6}$ John Searle, Mind, Language and Society: Doing Philosophy in the Real World (London: Weidenfeld and Nicolson, 1999), 149.

(C) 2018 Joseph Martin M. Jose and Napoleon M. Mabaquiao, Jr. https://www.kritike.org/journal/issue 23/jose\&mabaquiao december2018.pdf ISSN 1908-7330 


\section{RESOLVING THE GETTIER PROBLEM}

this person what I know. In the language of Austin, my speech act in this situation is abused, and hence a failure (or "unhappy," as Austin puts it). ${ }^{7}$

The purpose of stating a proposition is to assert that something is the case; and we can only assert that something is the case if we believe it to be the case. This purpose is what Searle refers to as the illocutionary point of the assertive class: "The point of the assertive speech acts is to commit the hearer to the truth of the proposition. It is to present the proposition as representing a state of affairs." ${ }^{8}$ Belief is, therefore, necessary for knowledge, for it is a necessary condition (acting as the proposition's sincerity condition) for stating the proposition that one claims to know. But is belief sufficient for knowledge? No, for not all of our beliefs are true; and truth is also necessary for knowledge. If someone, for instance, claims to know that Earth has three moons or that 2 and 2 are 6 , we will surely respond that he/she does not really know what he/she is talking about, even though he/she believes them to be true. This is because we know that what he/she claims to know is false. For knowledge to obtain, one cannot just believe a proposition; rather, that proposition must also be true. Of course, there are various contending positions as to when one can legitimately say that a proposition is true. ${ }^{9}$ This, however, does not change the fact that truth, in addition to belief, is a necessary condition for knowledge.

So then, are belief and truth already sufficient for knowledge? Not yet. Consider the fact that one can form one's belief based on mere hunch or lucky guesses, which later on turns out to be true. ${ }^{10}$ An example is a belief that it is presently raining in another part of the country, which is based on reading a forecast of a fake news agency. Now suppose that it is actually raining in that part of the country, then one's belief is true even though one's belief is based on faulty grounds. But can we say that this person does indeed know that it is raining in another part of the country? No, for how we come to know the truth of our beliefs also matters. What we believe to be true must be based on good grounds, reasons, or evidences. These good grounds, reasons, and evidences upon which our belief of a true proposition must rest are what we call justification. Justification is thus the third necessary

\footnotetext{
${ }^{7}$ J.L. Austin, How to do Things with Words (Oxford: Oxford University Press, 1962), 12 24; and J.L. Austin, "Performative-Constative," in The Philosophy of Language, ed. by John Searle (Oxford: Oxford University Press, 1971), 13-22.

${ }^{8}$ Searle, Mind, Language and Society, 148.

${ }^{9}$ There are, for instance, the three main theories on truth, namely, the correspondence, coherence, and pragmatic theories of truth. In the main, the correspondence theory claims that $\mathrm{X}$ is true if and only if $X$ corresponds to facts (or states of affairs in the world); the coherence theory argues that $X$ is true if and only if $X$ coheres to a given set of propositions/beliefs; and the pragmatic theory states that $\mathrm{X}$ is true if and only if $\mathrm{X}$ is useful. See Noah Lemos, An Introduction to the Theory of Knowledge (Cambridge: Cambridge University Press, 2007), 9-12.

${ }^{10}$ Lemos, An Introduction to the Theory of Knowledge, 6.
}

(c) 2018 Joseph Martin M. Jose and Napoleon M. Mabaquiao, Jr. https://www.kritike.org/journal/issue 23/jose\&mabaquiao december2018.pdf ISSN 1908-7330

(c) BY-NC-ND 
condition for knowledge. To know that $p$, we should believe that $p$, $p$ must be true, and our belief that $p$ is true must be justified.

Now, the two Gettier cases are intended to serve as two counterexamples to the JTB account, whereby the three conditions are believed to have obtained and yet we cannot allegedly claim that knowledge has likewise obtained. For our purposes, we shall, however, focus only on the first case, as all of the other attempts to engage Donnellan's theory of definite descriptions only dealt with the first case. More importantly, it is because it is the first case that is directly open for linguistic analysis, for which Donnellan's theory is one strategy. As such, our conclusion will, therefore, also be limited only to the first case. Now whether our analysis of this first case extends to the second one is something that would require another research. Offhand, since the second Gettier case operates on strictly logical terms and rules, its analysis would require a strategy that is more logical rather than linguistic. In any case, before we present the first Gettier case, it is important to take note that Gettier has some assumptions in his critique of the JTB account. First, Gettier assumes that "it is possible for a person to be justified in believing a proposition that is in fact false."11 Second, Gettier subscribes to the Principle of Deductive Closure, 12 according to which: "for any proposition $P$, if $S$ is justified in believing $P$, and $P$ entails $Q$, and $S$ deduces $Q$ from $P$ and accepts $Q$ as a result of this deduction, then $S$ is justified in believing Q." ${ }^{13}$ In short, this principle tells us that justification can be transmitted via deduction from one proposition to another.

Gettier's first case asks us to suppose that two men, Smith and Jones, are applying for a certain job. ${ }^{14}$ While waiting, Smith is informed by the president of the company that Jones will be the one who will get the job. Furthermore, Smith earlier found out that Jones has ten coins in his pocket. From these two evidences, Smith formulates the conjunctive proposition that: (d) "Jones is the man who will get the job, and Jones has ten coins in his pocket." From this proposition, Smith deduces the proposition: (e) "The man who will get the job has ten coins in his pocket." Through the Principle of

${ }^{11}$ Gettier, “Is Justified True Belief Knowledge?," 121. Noah Lemos provides some illustrative examples: "Suppose, for example, you are justified in believing that it is noon. You are justified because you have just looked at your watch around midday and it says that it is noon. But suppose that, unbeknownst to you, your watch stopped working at noon and it is now 12:30. Given your evidence, your belief is justified but false. Again, I might be justified in believing that the person I see going into the library is Lisa. I am justified because the person I see looks, dresses, and behaves just like Lisa. But suppose that, unbeknownst to me, Lisa has an identical twin and the person I see is not Lisa, but her twin. My belief that the person I saw was Lisa is false, but justified." See Lemos, An Introduction to the Theory of Knowledge, 14.

12 Lemos, An Introduction to the Theory of Knowledge, 24-25.

${ }^{13}$ Gettier, "Is Justified True Belief Knowledge?," 121.

${ }^{14}$ Ibid., 122.

(C) 2018 Joseph Martin M. Jose and Napoleon M. Mabaquiao, Jr. https://www.kritike.org/journal/issue 23/jose\&mabaquiao december2018.pdf ISSN 1908-7330 


\section{RESOLVING THE GETTIER PROBLEM}

Deductive Closure, Smith is justified in believing that proposition (e) is true which he deduces from proposition (d), which in turn he is justified in believing based on the two evidences. But then Gettier further asks us to imagine that unknown to Smith, it is he who will get the job and that he himself has ten coins in his pocket. Gettier remarks:

Proposition (e) is then true, though proposition (d), from which Smith inferred proposition (e) is false. In our example, then, all of the following are true: (i) (e) is true, (ii) Smith believes that (e) is true, and (iii) Smith is justified in believing that (e) is true. But it is equally clear that Smith does not know that (e) is true; for (e) is true in virtue of the number of coins in Smith's pocket, while Smith does not know how many coins are in Smith's pocket, and bases his belief in (e) on a count of the coins in Jones's pocket, whom he falsely believes to be the man who will get the job. ${ }^{15}$

Throughout the decades after Gettier formulated his two cases, there are epistemologists who created their own "Gettier cases."16 For instance, Roderick Chisholm formulated his sheep in the field case wherein we are asked to imagine that a person, say Luke, is standing in front of a field and that in front of Luke there is a sheep. ${ }^{17}$ Luke then formulates the proposition, "There is a sheep in the field." But unknown to Luke, the sheep that he sees is not really a sheep but a dog disguised as a sheep. But also unknown to Luke, there is in fact a sheep in the field but hiding behind the hill in the field. Hence, Luke has a justified true belief that there is a sheep in the field. But can one say that Luke has indeed knowledge that there is a sheep in the field?

\section{Approaches to the Gettier Problem}

Following Allan Hazlett, the various attempts to respond to the Gettier problem can be divided into two periods: the $20^{\text {th }}$ century and the $21^{\text {st }}$

${ }^{15}$ Ibid.

${ }^{16}$ For our purposes, we will only discuss the sheep in the field case since that will only be the focus of our analysis later and that such a case is sufficient to show that our analysis later can, in a sense, be extended to other versions of the Gettier cases and not just limited to what Gettier originally formulated. For the other cases, see Brian Skyrms, "The Explication of ' $X$ knows that $\mathrm{p}^{\prime}$," Journal of Philosophy, 64 (1967), 373-389, for the pyromaniac case. And see Alvin Goldman, "Discrimination and Perceptual Knowledge," Journal of Philosophy, 73 (1976), 771-791, for the fake barns case.

${ }^{17}$ Roderick Chisholm, Theory of Knowledge (New Jersey: Prentice Hall, 1966), 23.

(c) 2018 Joseph Martin M. Jose and Napoleon M. Mabaquiao, Jr. https://www.kritike.org/journal/issue 23/jose\&mabaquiao december2018.pdf ISSN 1908-7330

$((c))$ BY-NC-ND 
century. ${ }^{18}$ The former is what epistemologists traditionally call the "postGettier period," referring to the first few decades of research done about the Gettier problem. Hazlett provides a succinct survey of this period:

Some (Clark 1963) argued that knowledge cannot be derived from a false premise; others (Lehrer and Paxson 1969) argued that knowledge requires indefeasible justification; others (Goldman 1967) argued that knowledge must be caused by the truth of the proposition known; others (Stine 1967; Goldman 1976; Dretske 1981, Chapter 4) argued that knowledge requires the elimination of relevant alternatives; others (Nozick 1981, Chap. 3; Sosa 1999; Williamson 2000) argued that knowledge requires sensitivity (that you would not believe that $p$, were it not true that $p$ ) or safety (that you would not easily believe falsely that $p$ ). Externalist theories of knowledge flourished during this period-where these are (roughly) those that allow necessary conditions on knowledge (apart from the truth condition) the obtaining of which may be (in some sense) inaccessible to the knower. ${ }^{19}$

As we can observe, the contending positions on how to properly resolve the Gettier problem during this period, as cited by Hazlett, all made use of the strategy whereby the conditions of knowledge are modified in order to accommodate the Gettier cases. There are, however, also approaches during this period that utilize the strategy whereby Gettier's assumptions are put into question. ${ }^{20}$ They include approaches that reject the Principle of Deductive Closure and the assumption that we can be justified in believing a false proposition.

On the other hand, the approaches of the $21^{\text {st }}$ century attempts are more eclectic. One approach questions the very source of the Gettier problem and the solubility of it. It argues, for instance, that the problem has something to do about the nature of luck and our assumptions about the nature of knowledge. ${ }^{21}$ Yet another approach employs metaphilosophical research methods to deal with the epistemological assumptions regarding our

${ }^{18}$ Allan Hazlett, "The Maturation of the Gettier Problem," Philosophical Studies, 172:1 (2015), 2-3.

19 Ibid., 2.

${ }^{20}$ Lemos, An Introduction to the Theory of Knowledge, 25-26.

21 See Linda Zagzebski, "The Inescapability of Gettier Problems," Philosophical Quarterly, 44:174 (1994), 65-75.

(c) 2018 Joseph Martin M. Jose and Napoleon M. Mabaquiao, Jr. https://www.kritike.org/journal/issue 23/jose\&mabaquiao december2018.pdf ISSN 1908-7330 


\section{RESOLVING THE GETTIER PROBLEM}

intuitions on what knowledge is. This approach involves the method of experimental philosophy in order to examine the nature and evidential status of philosophical intuitions. ${ }^{22}$ One notable finding in this approach is that the intuition that knowledge is not present in Gettier cases is only common among non-Asian people, which shows, among others, that there is a discrepancy between the intuitions of epistemologists and lay people, and among the intuitions of lay people of different contexts/backgrounds. ${ }^{23}$ Lastly, there are attempts in the $21^{\text {st }}$ century whose approaches go beyond the confines of epistemology, such as those which utilize theories about the nature of intentional action and luck. ${ }^{24}$ But one of the most promising approaches during this period is the one that aligns itself with the so-called "linguistic turn" in the analytic tradition, whereby philosophical issues are generally regarded as questions about language, or as arising from certain forms of linguistic confusion.

The linguistic approach to the Gettier problem makes use of the various theories of meaning in the (analytic) philosophy of language. A major criticism of the linguistic philosophers against the Gettier problem is that it exploits the principles of logic to argue for cases that may not or do not even happen in our ordinary everyday lives or arise from our linguistic expressions in our everyday communications. It further contends that the circumstances in the Gettier cases, along with their truth claims, are not how our epistemic situation works in everyday circumstances. In this regard, some linguistic philosophers argue that "the form of a statement alone does not provide sufficient basis for judging its truth in normal everyday discourse, that is, natural language, which happens to be the domain of the Gettier cases." ${ }^{25}$ For them, the exploitative use of logic as evidenced by the use of the Principle of Deductive Closure, Principle of Existential Generalization, and Principle of Disjunction Introduction ${ }^{26}$ have taken for granted the role that

\footnotetext{
${ }^{22}$ See Ernest Sosa, "Can there be a Discipline of Philosophy? And can it be Founded on Intuitions?," Mind and Language, 26:4 (2011), 453-467.

${ }^{23}$ See Joshua Knobe and Shaun Nichols, Experimental Philosophy (Oxford: Oxford University Press, 2008), and Weinberg, Nichols, and Stich, "Normativity and Epistemic Intuitions," 429-460.

24 See Duncan Pritchard, Epistemic Luck (Oxford: Oxford University Press, 2005). (2016), 453

25 Yussif Yakubu, "Truth Analysis of the Gettier Argument," Metaphilosophy, 47:3

${ }^{26}$ As a recap, the Principle of Deductive Closure states that "for any proposition $\mathrm{P}$, if $\mathrm{S}$ is justified in believing $\mathrm{P}$, and $\mathrm{P}$ entails $\mathrm{Q}$, and $\mathrm{S}$ deduces $\mathrm{Q}$ from $\mathrm{P}$ and accepts $\mathrm{Q}$ as a result of this deduction, then $\mathrm{S}$ is justified in believing Q" [see Gettier, "Is Justified True Belief Knowledge?" 121]. In short, this principle tells us that justification can be transmitted via deduction from one proposition to another. On the other hand, the Principle of Existential Generalization is "used to infer an existentially quantified formula from a formula which tells us something about some named individual .... For example, consider the simplest possible case of such an inference in natural language. Given 'Arlo Guthrie is a folk singer' I might go on to infer
}

(c) 2018 Joseph Martin M. Jose and Napoleon M. Mabaquiao, Jr. https://www.kritike.org/journal/issue 23/jose\&mabaquiao december2018.pdf ISSN 1908-7330

(c) $)$ BY-NC-ND 
content, context, state of mind, and other extralocutionary factors plays in making sense of the Gettier cases and of our epistemic situations in general. ${ }^{27}$ Such factors are all taken for granted in the epistemological discourse, leading epistemologists, arguably including Gettier, to overlook, if not forget, that natural language and classical logic have different ways of approaching truth. 28

Yussif Yakubu, in his article "Truth Analysis of the Gettier Argument," provides a preliminary sketch of how linguistic approaches to the Gettier problem may proceed in the future. He argues that "an analysis that incautiously deploys the tools of classical logic in evaluating the truth of propositions in practical discourse involving natural language courts error, and the Gettier cases involve analysis of this kind." ${ }^{29}$ He then proceeds to demonstrate such claim by making use of certain theories in the philosophy of language. These theories include P.F. Strawson's distinction of a sentence and a use of a sentence, Immanuel Kant's dichotomy of analytic and synthetic statements, Donnellan's referential and attributive uses of definite descriptions, analytic philosophy's de dicto and de re distinction, Saul Kripke's distinction between semantic reference and speaker's reference (in which Yakubu argues that Kripke's semantic reference parallels the conversational implicature of H.P. Grice), and the uniquely referring phrase of Strawson. ${ }^{30}$ With these various distinctions in our linguistic expressions in mind, Yakubu expects that the conflation of one concept/use/principle with another concept/use/principle in the Gettier cases which brings about the confusions in the Gettier problem will finally disappear. ${ }^{31}$ The linguistic approaches to the Gettier problem that Yakubu finds most promising are those that make use of Kripke's distinction between semantic reference and speaker's reference, and of Donnellan's distinction between the referential and attributive uses of definite descriptions.

One who endorses Kripke's semantic and speaker references as a linguistic approach to the Gettier problem is Moti Mizhari. Mizhari claims that the Gettier cases merely appear to be cases of epistemic failure, for they

'There exists at least one folk singer'." [see Paul Tomassi, Logic (London: Routledge, 1999), 281282]. Lastly, the Principle of Disjunction Introduction states that "given any formula on any line of proof, [such principle] allows us to infer immediately the disjunction of that formula with any other well-formed formula we care to choose. In other words, [it] allows us to take any formula from any line of proof, to write that formula on a new line together with ' $v$ ' and to complete the disjunction with absolutely any other well-formed formula we might like the look of." [see Tomassi, Logic, 83].

${ }^{27}$ Yakubu, "Truth Analysis of the Gettier Argument," 453.

${ }^{28}$ Ibid.

${ }^{29}$ Ibid., 465.

30 Ibid., 459 .

${ }^{31}$ Ibid., 455.

(C) 2018 Joseph Martin M. Jose and Napoleon M. Mabaquiao, Jr. https://www.kritike.org/journal/issue 23/jose\&mabaquiao december2018.pdf ISSN 1908-7330 


\section{RESOLVING THE GETTIER PROBLEM}

are actually cases of semantic failure caused by the presence of what Kripke calls "ambiguous designators." These designators make the Gettier cases misleading because there can be an ambiguity with regard to whether they employ speaker reference or semantic reference. ${ }^{32}$ Accordingly, the ambiguous designator at issue is the definite description "the man who will get the job." Its speaker reference is Jones, while its semantic reference is whoever will fit the description "the man who will get the job."

Yakubu, in his analysis, finds the linguistic approach based on Kripke's distinction similar in nature to Donnellan's: Kripke's semantic reference corresponds to Donnellan's attributive use; and Kripke's speaker's reference to Donnellan's referential use. ${ }^{33}$ According to Yakubu, using the framework of Donnellan's theory of definite description, what is ambiguous with regard to the said definite description is how it is used in the proposition "The man who will get the job has ten coins in his pocket," as uttered by Smith. ${ }^{34}$ Accordingly, Smith uses it referentially as Smith has Jones in mind, while Gettier understands its use in the attribute sense-that is, whoever fits the description specified by the definite description. For our purposes in this essay, we shall elaborate on the Donnellan linguistic approach to the Gettier problem. While we find Yakubu in the right direction in his own analysis of how the Donnellan linguistic approach will proceed in resolving the Gettier problem, he, however, does not delve into the details of this approach, as his main objective in his essay is simply to provide a preliminary sketch as to how a linguistic approach to the Gettier problem can be done. ${ }^{35}$ Our purpose then is to fill in what is lacking in Yakubu's account: ${ }^{36}$ we intend to provide

${ }^{32}$ Moti Mizhari, “Why Gettier Cases Are Misleading?” Logos E Episteme, 7:1 (2016), 31-

44.

${ }^{33}$ For further analysis of this point, see also Philip Atkins' reply to Mizhari's arguments. See Philip Atkins, “Are Gettier Cases Misleading?" Logos \& Episteme, 7:3 (2016), 379_ 384 .

${ }^{34}$ Yakubu, "Truth Analysis of the Gettier Argument," 457-458.

${ }^{35}$ It is interesting to note that Konstanz Christoph Schimdt-Petri also made use of Donnellan's distinction in arguing that Gettier's example is flawed. He provides both a referential and attributive reading of the cases. However, what makes his analysis different is that he argues that what is violated is the belief condition in the JTB, on the other hand, for our case and Yakubu's, it is the truth condition which is our concern. Thus, this paper will be explicating further such initiative. See Konstanz Christoph Schimdt-Petri, "Is Gettier's First Example Flawed?" in Knowledge and Belief, ed. by Winfried Loffler and Paul Weingartner (Austrian Ludwig Wittgenstein Society, 2003), 317-319.

${ }^{36}$ Furthermore, Yakubu claims that there are some versions of the Gettier cases that do not involve a definite description; hence, using Donnellan's theory of definite descriptions as a framework would not be applicable all the time [see Yakubu, "Truth Analysis of the Gettier Argument," 457]. However, we find that in so far as the existing Gettier cases in the literature are concerned, they contain a definite description although not explicitly stated. Hence, what is needed is to reword those Gettier cases in such a way that a definite description can be obviously seen. We have to remember that not all the succeeding versions of the original Gettier cases

(c) 2018 Joseph Martin M. Jose and Napoleon M. Mabaquiao, Jr. https://www.kritike.org/journal/issue 23/jose\&mabaquiao december2018.pdf ISSN 1908-7330

(cc) BY-NC-ND 
the necessary explanation for how the Donnellan linguistic approach can be used effectively in resolving, or dissolving, the Gettier problem as presented in the first case (the Smith case).

\section{The Donnellan Linguistic Strategy}

Donnellan, in his paper "Reference and Definite Descriptions," argues that definite descriptions (expressions that come in the form "the so and so") have two functions: attributive and referential. ${ }^{37}$ When someone uses a definite description attributively, he/she "states something about whoever or whatever is the so-and-so." 38 On the other hand, when someone uses a definite description referentially, he/she "uses the description to enable his audience to pick out whom or what he is talking about and states something about that person or thing." 39

In an assertion, when a definite description is used attributively such definite description functions as a sort of essence. It is because "one wishes to assert something about whatever or whoever fits that description." 40 Hence, the "attribute of being the so-and-so is all important." 41 On the other hand, when a definite description is used in an assertion referentially, such definite description is just one among many tools by which one can use in order to point out, pick out, or call to one's attention a person or thing which other linguistic devices/tools could perform as well. ${ }^{42}$ Hence, "the attribute of being the so-and-so is not important." ${ }^{43}$ To illustrate, let us consider an example

followed the format and wordings of Gettier in his paper. The sheep in the field, pyromaniac and fake barns cases are examples.

${ }^{37}$ Keith Donnellan's distinction between the attributive and referential uses of definite descriptions is a response to Bertrand Russell and P.F. Strawson's views on definite descriptions. One of the main contentions of Donnellan is that Russell and Strawson's view is incomplete in that their understanding of the function of definite descriptions is limited only in the attributive use; hence, making their theory incomplete. According to Donnellan, definite descriptions do not only have an attributive use; but also a referential use. In fairness to Russell, it is not really the case that Russell does not acknowledge the referential use of definite descriptions as used in ordinary language; what he simply claims is that in a logically perfect language, definite descriptions should only be used attributively for using it referentially will confuse it with the function of proper names. The importance of Donnellan's clarification of these two uses of definite descriptions in the context of ordinary language, however, goes beyond its being a critique of Russell's theory of definite descriptions, for being able to resolve certain linguistic puzzles.

${ }^{38}$ Keith Donnellan, "Reference and Definite Descriptions," The Philosophical Review, 75:3 (1966): 285.

${ }^{39}$ Ibid.

${ }^{40}$ Ibid.

${ }^{41}$ Ibid.

${ }^{42}$ Ibid.

${ }^{43}$ Ibid.

(C) 2018 Joseph Martin M. Jose and Napoleon M. Mabaquiao, Jr. https://www.kritike.org/journal/issue 23/jose\&mabaquiao december2018.pdf

ISSN 1908-7330 
given by Donnellan: the proposition "Smith's murderer is insane." 44 Imagine that Smith's good friend, Henry, comes across Smith's body on the road whose body parts are fragmented. Smith's head decapitated, the bones in his arms and legs protruding out of his skin. His clothes soaked in his own blood. All of this points to Smith being murdered in an unimaginable, heinous way. Henry then forms an assertion saying that "Smith's murderer is insane." Such an assertion contains a definite description, "the person who murdered Smith" here expressed simply as "Smith's murderer," which Donnellan says is used in the attributive sense, for Henry does not intend that his definite description be a tool to aid his audience to pick out whomever he is talking about. Rather, Henry uses it to say something about whoever satisfies such description (i.e., whoever murdered Smith is insane). Henry has no particular person in mind in making such an assertion, for he does not know who murdered Smith. Anyone who satisfies the description qualifies as that someone whom Henry is talking about.

On the other hand, consider the same assertion "Smith's murderer is insane," this time uttered by another good friend of Smith, Jack, while witnessing the trial of the person suspected to be Smith's murderer is being cross-examined. Let us suppose that this person is named Jones. Jack has known about the way his friend Smith has been murdered; and he is convinced that the person who did this was Jones. When Jack utters the assertion "Smith's murderer is insane," Jack uses the definite description "Smith's murderer" (or "the man who murdered Smith"), according to Donnellan, in the referential sense, for Jack is using the definite description to help the people around him pick out the person he is talking about. Now whether or not it is true that Jones is the murderer of Smith (in other words, whether Jones fits the description of the definite description) is not important because the definite description is only used as a tool to make the audience pick out what Jack is talking about.

The difference between these two uses of the definite description can also be illustrated by how one answers a question containing a definite description. In a question, when one uses a definite description referentially, one "may succeed in picking out a person or thing to ask a question about even though he or it does not really fit the description." ${ }^{45}$ On the other hand, when one uses a definite description in a question attributively, "if nothing fits the description, no straightforward answer to the question can be given." ${ }^{46}$ To illustrate, imagine that we are in a party and looking at a person that one is interested about. ${ }^{47}$ One then asks one's friend the question "Who

\footnotetext{
${ }^{44}$ Ibid., 285--286.

${ }^{45}$ Ibid., 287.

${ }^{46}$ Ibid.

${ }^{47}$ Ibid.
}

(c) 2018 Joseph Martin M. Jose and Napoleon M. Mabaquiao, Jr. https://www.kritike.org/journal/issue 23/jose\&mabaquiao december2018.pdf ISSN 1908-7330

(c) BY-NC-ND 
is the person drinking martini?" If the definite description "the person drinking martini" is used referentially, and one succeeds in leading one's hearer to pick out the individual one is talking about in the question, the question can still be answered if it happens that the individual is not really drinking martini but water. But, if the definite description is used attributively, and the individual one is talking about is not drinking martini, then the question cannot be answered for the individual does not fit the attribute specified in the definite description. In this case, the attribute is what is important and not the person. The attribute must be satisfied in order for the question to have a straightforward answer.

In commands or orders, "when a definite description is used attributively....and nothing fits the description, the command cannot be obeyed...."48 On the other hand, when a definite description is used referentially, whether or not the person or thing fits the description, the command or order can still be obeyed. For example, Donnellan asks us to imagine that someone is ordered, "bring me the book on the table." If the command is used referentially but the book happens not to be on the table but beside or under it, this command can still be obeyed and one may return to the person issuing such command with the right book at hand. ${ }^{49}$ It is because the attribute of being on the top of the table is not important since both of them knew in their minds what book they are talking about. On the other hand, if such a definite description was used attributively, then the command cannot be obeyed at all if there is no book on the table or if the book is beside or under such table. It is because what is important is the book fitting the description that it is on top of the table.

Let us now look into how the difference of the two uses of definite descriptions will show that that there is a confusion between Gettier's understanding of Smith's epistemic situation and Smith's understanding of his own situation. By epistemic situation we simply mean a circumstance wherein knowledge is at play or is at stake. As we have earlier noted, the definite description that is in question in the first original case, the Smith case, is "the man who will get the job." Now one may ask in what way is such definite description used in the case of Smith when he uttered the proposition "The man who will get the job has ten coins in his pocket?" To begin with, there are two perspectives that have to be considered here. One is the perspective of Smith (which is Smith's experience of his own epistemic situation), and second is the perspective of Gettier (which is his analysis/understanding of the epistemic situation of Smith). From the perspective of Smith, he uttered such a proposition after having been justified

48 Ibid., 288.

${ }^{49}$ Ibid., 287-288.

(c) 2018 Joseph Martin M. Jose and Napoleon M. Mabaquiao, Jr. https://www.kritike.org/journal/issue 23/jose\&mabaquiao december2018.pdf ISSN 1908-7330 


\section{RESOLVING THE GETTIER PROBLEM}

with the evidences (a) that the president of the company told him that Jones would surely be the one who would get the job, and (b) that he knew that Jones had ten coins in his pocket (upon earlier counting them). This only means that the person that Smith has in mind in uttering such definite description and supported by the evidences the he has is Jones. It is Jones and only Jones that Smith has in mind in using the definite description "the man who will get the job." In fact, Smith could have used other definite descriptions to pick out Jones such as "The man whom the president has chosen" or "The man who was with me in the waiting room." Whichever of these that Smith might have used, it will not change the person that he has in mind, which is Jones.

We can thus say that Smith uses the definite description in the referential sense. If we situate such definite description in the JTB, indeed in his belief that "The man who will get the job has ten coins in his pocket," he is referring to Jones and Jones alone. Furthermore, the truth of his proposition, in which the definite description appears, should be determined only in the context of the referential use of the definite description; that is, if it is indeed Jones who will get the job and that he has ten coins in his pocket. If it is not Jones who will get the job, regardless of whether Jones has ten coins in his pocket, the proposition is false. ${ }^{50}$

What is crucial here, however, is when we take into consideration the perspective of Gettier. As we have seen in the original Gettier case, there was something strange that occurred. It was Smith who got the job and that Smith himself has ten coins in his pocket. From such occurrence, Gettier then says that the proposition (e) "The man who will get the job has ten coins in his pocket" is true by virtue of Smith (1) having gotten the job and (2) having also ten coins in his pocket. Smith's belief that proposition (e), according to Gettier, is still true even though what Smith has in mind is Jones. Further, Smith is still justified in believing proposition (e) since his belief is based on evidences and grounds by which he is really justified in having. As we can see, the analysis clearly shows that Gettier is using the definite description, or understands Smith's use of the definite description, in the attributive way because he does not really care about the fact that what Smith has in mind is Jones. What he cares about is to state that whoever will fit the description "the man who will get the job" has ten coins in his pocket.

Smith and Gettier differ as to how they understand the use of the definite description in Smith's proposition. But whose use is the right one?

${ }^{50}$ The proposition "The person who will get the job has ten coins in this pocket," is actually a conjunction of two propositional functions; namely: " $X$ will get the job" and " $X$ has ten coins in his pocket." So, if one of these functions will yield a false proposition, the original function is automatically false, regardless of whether the other propositional function will yield a true proposition.

(c) 2018 Joseph Martin M. Jose and Napoleon M. Mabaquiao, Jr. https://www.kritike.org/journal/issue 23/jose\&mabaquiao december2018.pdf ISSN 1908-7330

$(\mathrm{Cc}) \overline{\mathrm{BY}-\mathrm{NC}-\mathrm{ND}}$ 
Definitely the person uttering the proposition, which is Smith, for it is Smith who is making a knowledge claim with regard to the proposition "The man who will get the job has ten coins in his pocket." The question is whether Smith really knows $\mathrm{p}$ when he utters $\mathrm{p}$; and not whether Gettier knows $\mathrm{p}$ when Smith utters p. It is Smith who has the belief in question and the justification in question for the truth of this belief. What we are considering is the epistemic situation of Smith, whether it is an instance of JTB; and not the epistemic situation of Gettier.

Now given that Smith uses the definite description "the man who will get the job" in his proposition "The man who will get the job has ten coins in his pocket" in the referential sense, this proposition of his is not true but false given that it is Smith, and not Jones, who will get the job. If this proposition is false, then Smith's proposition is not a case of JTB at all. For though the conditions of belief and justification are satisfied, the condition of truth is not. What in fact happened is that Gettier imposed his attributive understanding of the definite description onto Smith's own mind or epistemic situation.

This confusion can also be seen in the other versions of the Gettier cases. Although, there is no explicit definite description that can be extracted from such versions, the dynamics of the uses of definite descriptions can still be applied. For instance, in the case of the sheep in the field, the proposition "There is a sheep in the field" can have an attributive and referential uses. The man looking at a particular sheep in the field and then uttering the proposition "There is a sheep in the field" is operating in the referential use since he has that particular animal in mind. He is using such proposition for us, his audience, to pick out that animal he is referring to. On the other hand, the "Gettier" in this case used it attributively, in a sense that the truth of the proposition was not dependent on whether or not that sheep in front of him was indeed a sheep. The proposition being luckily true was based on a sheep that was behind the hill. Hence, what is important was there is a sheep that satisfies the definite description in the proposition. The "Gettier" does not care about the animal in front of the person.

If we now go back to the argument of Gettier, P2 states that "there are instances where JTB obtains, but knowledge does not obtain;" hence, leading him to conclude that JTB is not sufficient for knowledge. Gettier instantiated P2 via his two cases. Therefore, for Gettier, his two cases are cases of JTB. But our analysis shows the contrary. The case of Smith is in fact not a case of JTB. Having shown earlier that the truth condition does not hold makes Gettier's case problematic. It is because it fails to be a case of JTB, and if it fails to be one, then Gettier would not be able to push further his P2 since he has to make sure that the cases that will instantiate P2 are really cases of

(c) 2018 Joseph Martin M. Jose and Napoleon M. Mabaquiao, Jr. https://www.kritike.org/journal/issue 23/jose\&mabaquiao december2018.pdf ISSN 1908-7330 


\section{RESOLVING THE GETTIER PROBLEM}

JTB, but as we have shown, one of them is not. This then will put the whole argument of Gettier in question.

\section{Conclusion}

In this paper, we have attempted to respond to the Gettier problem by engaging in the so-called "linguistic turn" in the approaches to the Gettier problem. Specifically, we engaged Donnellan's distinction of the attributive and referential uses of definite descriptions to analyze the first Gettier case and a version of such case. In that analysis, we have shown that the definite description "the man who will get the job" in the proposition "The man who will get the job has ten coins in his pocket" is a definite description that can have an attributive and a referential function. Smith, within his own epistemic situation, makes use of such definite description referentially; on the other hand, Gettier, in his analysis of the epistemic situation of Smith, makes use of such definite description attributively. From such difference in uses, we have shown that there is an equivocation at play in the Gettier case. But since it is the epistemic situation of Smith that is in question, it is thus Smith's use of the definite description that should be considered. And in this regard, Smith's proposition is false, thereby disqualifying Smith's proposition as a case of JTB. Consequently, the Smith case fails to serve as a counterexample to the JTB account of knowledge.

Philosophy Department, De La Salle University, Manila, Philippines

\section{References}

Atkins, Philip, “Are Gettier Cases Misleading?" Logos \& Episteme, 7:3 (2016). Austin, J. L. How to do Things with Words (Oxford: Oxford University Press, 1962).

"Performative-Constative," in The Philosophy of Language, ed. by John Searle (Oxford: Oxford University Press, 1971).

Chisholm, Roderick, (Theory of Knowledge. New Jersey: Prentice Hall, 1966).

Christoph Schmidt-Petri, Konstanz, "Is Gettier's First Example Flawed?" in Knowledge and Belief, ed. by Winfried Loffler and Paul Weingartner (Austrian Ludwig Wittgenstein Society, 2003).

Dancy, Jonathan, An Introduction to Contemporary Epistemology (Oxford: Blackwell Publishing, 1985).

Donnellan, Keith, "Reference and Definite Descriptions," The Philosophical Review, 75:3 (1966).

Feldman, Richard, "An Alleged Defect in Gettier Counterexamples," Australasian Journal of Philosophy, 52 (1974).

(c) 2018 Joseph Martin M. Jose and Napoleon M. Mabaquiao, Jr. https://www.kritike.org/journal/issue 23/jose\&mabaquiao december2018.pdf ISSN 1908-7330

(c) $)$ BY-NC-ND 
Gettier, Edmund, “Is Justified True Belief Knowledge?" Analysis. 23:6 (1963). Goldman, Alvin, "A Causal Theory of Knowing," Journal of Philosophy, 64:12 (1967).

"Discrimination and Perceptual Knowledge," Journal of Philosophy, 73 (1976).

Hazlett, Allan, "The Maturation of the Gettier Problem," Philosophical Studies, 172:1 (2015).

Hetherington, Stephen, Good Knowledge, Bad Knowledge: On Two Dogmas of Epistemology (Oxford: Oxford University Press, 2000).

Lehrer, Keith, "Why Not Skepticism?" The Philosophical Forum, 2 (1971).

Lehrer, Keith and Thomas Paxson, Jr., "Knowledge: Undefeated Justified True Belief." Journal of Philosophy, 66:8 (1969).

Lemos, Noah, An Introduction to the Theory of Knowledge (Cambridge: Cambridge University Press, 2007).

Mabaquiao, Napoleon, Jr., Mind, Science and Computation (Quezon City: Vibal Publishing Inc. and De La Salle University, 2012).

Mizhari, Moti, “Why Gettier Cases are Misleading," Logos \& Episteme, 7:1 (2016).

Knobe, Joshua, and Shaun Nichols, Experimental Philosophy (Oxford: Oxford University Press, 2008).

Searle, John, Mind, Language and Society: Doing Philosophy in the Real World (London: Weidenfeld and Nicolson, 1999).

Skyrms, Brian, "The Explication of 'X knows that $\mathrm{p}^{\prime}$," Journal of Philosophy, 64:12.

Sosa, Ernest, "Can there be a Discipline of Philosophy? And can it be Founded on Intuitions?" Mind and Language, 26:4 (2011).

Tomassi, Paul, Logic (London: Routledge, 1999).

Unger, Peter, “A Defense of Skepticism." The Philosophical Review, 80:2 (1971): 198-219.

"An Analysis of Factual Knowledge" Journal of Philosophy, 65:6 (1968).

Weinberg, Jonathan, Shaun Nichols, and Stephen Stich, "Normativity and Epistemic Intuitions," in Philosophical Topics, 29:1/2 (2001).

Yakubu, Yussif, "Truth Analysis of the Gettier Argument," Metaphilosophy, 47:3 (2016).

Zagzebski, Linda, "The Inescapability of Gettier Problems," Philosophical Quarterly, 44:174 (1994).

(c) 2018 Joseph Martin M. Jose and Napoleon M. Mabaquiao, Jr. https://www.kritike.org/journal/issue 23/jose\&mabaquiao december2018.pdf ISSN 1908-7330 